\title{
THE EFFECT OF BROKEN HOMES ON SELF- ESTEEM AMONG ADOLESCENTS IN SUKA MAJU VILLAGE
}

\author{
Indri Reskiana*, Suwarjo, Faisal Asmen \\ *Correspondent Author
}

Indri Reskiana

Universitas Negeri Yogyakarta

Jalan Colombo Nomor 1 Karangmalang,

Yogyakarta

Indonesia

Email:

indrireskiana2019@student.uny.ac.id

Suwarjo

Universitas Negeri Yogyakarta

Jalan Colombo Nomor 1 Karangmalang,

Yogyakarta

Indonesia

Email: suwarjo@uny.ac.id

Indri Reskiana

Universitas Negeri Yogyakarta

Jalan Colombo Nomor 1 Karangmalang,

Yogyakarta

Indonesia

Email:

faisalasmen2019@student.uny.ac.id

\begin{abstract}
The study aims to determine the effect of a broken home family on adolescent self-esteem in Suka Maju Village. Respondents in this study were 36 teenagers from broken homes recruited using the purposive sampling technique. The data were collected using a questionnaire and self-esteem scale and analyzed using simple linear regression. The study found that broken homes significantly affected self-esteem among adolescents in Suka Maju Village. This study can serve as a reference for school counselors in developing the self-esteem of adolescents from broken homes.

Keywords: self esteem; broken home; adolescents
\end{abstract}

\section{INTRODUCTION}

Adolescence serves as a transitional phase from childhood to adulthood. This phase witnesses a significant, rapid physical, emotional, and intellectual development, challenging individuals to adjust to their social identity (Danim, 2013; Miranda, 2013; Chen et al., 2013). Among a range of issues an adolescent face, social problems regarding self-identity can lower self-esteem.

One of the factors affecting one's selfesteem is the family environment (Ghufron \&
Risnawita, 2016). Every individual is likely to be influenced by their family functions (Gladding, 2012). According to Lestari (2012), the family serves the basic instrumental and expressive functions for its members. Thus, family plays a pivotal role in influencing children's life (Rangkuti \& Mardiawan, 2015; Knafl et al., 2013; Porche et al., 2016). Previous studies assert that parents' behavior can affect their children's self-esteem (Rangkuti \& Mardiawan, 2015; Behnke et al., 2011). 


\title{
43 | PSIKOPEDAGOGIA
}

\author{
JURNAL BIMBINGAN DAN KONSELING
}

Vol.10, No.1, June 2021

A family condition is also known to significantly affect one's self-esteem. For example, high depression levels within a family, let alone a broken home family, can influence self-esteem. The term broken home is commonly used to refer to a disharmonious family due to conflicts, which often leads to arguments or even divorce (Abdullah et al., 2020; Firdausi et al., 2020; Muarifah et al., 2019).

The fact shows several broken homes in Suka Maju Village, which adversely influence children's development. The observation and interviews with adolescents in Sukamaju revealed that those from broken home families tend to withdraw from the environment, lack the confidence to socialize with their surroundings, often feel depressed, suffer from various academic and nonacademic difficulties at school. These symptoms represent a low level of selfesteem among adolescents from broken home families in Suka Maju Village.

As a low level of self-esteem is likely to become the source of problems an adolescent face, it is necessary to identify the broken family environment as one of the factors causing adolescents' low self-esteem. The present study aims to determine the effect of broken home families on adolescents' selfesteem. The result of the study can serve as a reference for school counselors to develop the self-esteem of adolescents from broken homes.

\section{RESEARCH METHOD}

This study employed correlational design. The participants were thirty-six adolescents from broken home families in Suka Maju Village, Riau Province, Indonesia, recruited using the purposive sampling technique. The data were collected using a questionnaire and self-esteem scale. The obtained data were analyzed using simple linear regression.

\section{RESULTS AND DISCUSSIONS}

The hypothesis on the effect of broken homes on adolescents' self-esteem was formulated into an alternative hypothesis $(\mathrm{Ha})$ and the null hypothesis $(\mathrm{Ho})$. $\mathrm{Ha}$, in this study, expected that a broken home family significantly affects adolescent's self-esteem in Suka Maju Village. Meanwhile, in this study, Ho stated that a broken home family does not affect adolescents' self-esteem in Suka Maju Village. The hypothesis was tested using simple linear regression analysis:

Table 1

Output Coefficient Summary

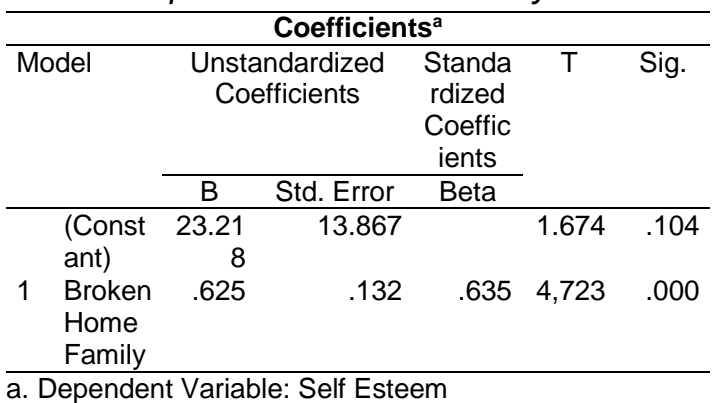

As displayed in the table, the constant obtained from simple linear regression analysis was 23.218. indicating that the broken home family affects self-esteem.

Table 2

Model Summary

\begin{tabular}{|c|c|c|c|c|}
\hline $\begin{array}{l}\text { Mo } \\
\text { del }\end{array}$ & $\mathrm{R}$ & R Square & $\begin{array}{l}\text { Adjusted R } \\
\text { Square }\end{array}$ & $\begin{array}{l}\text { Std. Error } \\
\text { of the } \\
\text { Estimate }\end{array}$ \\
\hline 1 & $.635^{a}$ & .403 & .398 & 6,354 \\
\hline
\end{tabular}

As presented in Table 2, broken family conditions influenced the adolescents' selfesteem by $40.3 \%$ and other variables outside this study by $59.7 \%$.

The term broken home is not only limited to divorced parents, but also dead parents, or parents who leave their home often due to work, resulting in poor interaction with other family members, and parents who fail to fulfill their children's needs of love.

It can be seen from two aspects: (1) The family does not have a complete structure because one of the parents die or divorced, (2) Parents are not divorced, but the family structure is no longer complete because the father or mother often leaves home and/or no longer show affections (Hammond \& Czyszczon, 2014; Sperry, 2013).

A broken home leads to a non-conducive house atmosphere as parents give little or no, attention to their children, which eventually 
adversely affects their development. Studies found that individuals from broken homes face more difficulties at school and are more aggressive, anxious, and sexually active. They are also reported to exhibit more withdrawal, less prosocial, and prone to drug abuse (Wangge \& Hartini, 2013; Fatchurrahmi \& Sholichah, 2020; Arma, 2019; Achilike, 2017). Broken home serves as one of the important variables that can affect adolescents' self-esteem, one's feeling of his/her value to judge his ability, either positively or negatively.

(Myers, 2015). Self-esteem constitutes an integration of self-confidence and self-respect (Rahman, 2013). In other words, self-esteem is one's positive or negative self-evaluation, affected by the interaction with significant others in the surroundings and their acceptance, respect, and treatment.

According to Bradshaw (Ghufron \& Risnawita, 2016), one's self-esteem has begun to develop since an infant feels the first pat when he or she is born. One's self-esteem is formed since one engages with social interaction and experiences. Excessive mockery, punishment, command, and prohibition can make children feel disrespected (Ghufron \& Risnawita, 2016: 41).

Self-esteem represents one's selfevaluation. The evaluation shows how individuals regard their existence and meaningfulness. Individuals with high selfesteem are likely to appreciate their strengths and potential while accepting their weaknesses. In contrast, individuals with low self-esteem are often unsatisfied with their own condition, find it difficult to appreciate their strength, and often see only their weakness (Istiana, 2017).

Self-esteem is an important element of adolescents' development, equally important to social, physical, and academic skill development. The previous study shows that self-esteem affects motivation, functional behavior, life decision and is significantly related to adolescents' lifelong wellbeing (Nikmarijal \& Ifdil, 2014). Adolescents with high self-esteem view themselves as valuable, successful, and meaningful. In contrast, those with low self-esteem are likely to see themselves as useless, unwanted, and meaningless. Individuals with low self-esteem may find it difficult to respect themselves and their surroundings (Srisayekti et al., 2015). Low self-esteem is also reported to be associated with negative phenomena, including premarital pregnancy, drug abuse, violence, depression, social anxiety, and even suicide (Fitriah \& Hariyono, 2019).

Meanwhile, from the positive lens, high self-esteem is associated with satisfactory learning achievement (Refnadi, 2018). It is important for adolescents to have a high selfesteem level, as individuals with high selfesteem are likely to be optimistic, confident, and aware of their weaknesses, then turn it into a challenge to develop.

Self-esteem is known to affect adolescents' learning process at school. (Refnadi, 2018). Adolescents with high selfesteem are reported to have higher achievement. Similarly, another study also reports that self-esteem significantly influences adolescents' academic achievement (Wibowo, 2014). The study implies the importance of self-esteem in affecting adolescents' academic achievement. Adolescents with higher selfesteem are associated with higher learning achievement, whereas lower self-esteem is related to poor learning achievement (Irawati \& Hajat, 2012).

The result of the study can serve as the reference for future studies to explore, more specifically, the effect of low self-esteem. Considering that self-esteem can affect adolescents' academic and non-academic aspects, school counselors need to pay attention to one's self-esteem when providing guidance and counseling services. School counselors can organize and design an effective guidance and counseling strategy to help adolescent improve their self-esteem by considering broken homes as the influencing variable.

This study is also useful for parents to pay attention to their child's condition and family condition to improve children's self-esteem and develop a harmonious, happy family. 


\title{
45 | PSIKOPEDAGOGIA
}

\author{
JURNAL BIMBINGAN DAN KONSELING
}

Vol.10, No.1, June 2021

\section{CONCLUSION}

This study found that broken home family serves as one of the variables influencing adolescent self-esteem. This study can be used as a reference for school counselors when designing guidance and counseling services to help adolescents from broken homes enhance their self-esteem. Adolescents with high self-esteem are expected to be able to develop their potential and exhibit optimal growth.

\section{REFERENCE}

Abdullah, E. S. P. S., Winarsunu, T., \& Yuniardi, M. S. (2020). The Effect of Self Esteem Group Therapy on Distress Tolerance of Broken Home Teenagers. Journal of Psychiatry and Psychology Research, 3(5), 266271.

Achilike, B. A. (2017). Effect Of Broken Home On Students' Academic Achievement In Ohaukwu Local Government Area Of Ebonyi State South East Nigeria. International Journal of Recent Advances in Multidisciplinary Research, 4 (5), 2581-2586.

Arma, M. S. (2019, December). The Impacts of Self-Esteem Development to Children from a Broken Home Family. In International Conference on Education Technology (ICOET 2019) (pp. 89-92). Atlantis Press.

Behnke, A. O., Plunkett, S. W., Sands, T., \& Bámaca-Colbert, M. Y. (2011). The Relationship Between Latino Adolescents' Perceptions of Discrimination, Neighborhood Risk, And Parenting on Self-Esteem And Depressive Symptoms. Journal of Cross-Cultural Psychology, 42(7), 1179-1197.

Chen, J., Li, X., Zhang, J., Natsuaki, M. N., Leve, L. D., Harold, G. T., ... \& Ge, X. (2013). The Beijing Twin Study (BeTwiSt): A Longitudinal Study of Child And Adolescent Development. Twin Research and Human Genetics, 16(1), 91-97.

Danim, S. (2013). Perkembangan Peserta Didik. Bandung: Alfabeta.

Fatchurrahmi, R., \& Sholichah, M. (2020). Mindfulness for Adolescents from Broken Home Family. Nternational Journal of Latest Research in Humanities and Social Science (IJLRHSS), 4(02), 60-65.
Firdausi, N. I. A., Hotifah, Y., \& Simon, I. M. (2020). Psychological Dynamics of Young People on Broken Home Families. Acta Counseling and Humanities, 1(1), 31-41.

Fitriah, A., \& Hariyono, D. S. (2019). Hubungan Self Esteem Terhadap Kecenderungan Depresi Pada Mahasiswa. Psycho Holistic, 1(1), 817.

Ghufron, M. N. dan Risnawita, R. (2016). Teori-Teori Psikologi. Jogyakarta: ArRuzz Media.

Gladding, S. T. (2012). Konseling: Profesi yang menyeluruh, Edisi Keenam. Jakarta Barat: PT Indeks.

Hammond, C., \& Czyszczon, G. (2014). Home-Based Family Counseling: An Emerging Field In Need Of Professionalization. The Family Journal, 22(1), 56-61.

Irawati, N., \& Hajat, N. (2012). Hubungan Antara Harga Diri (Self-Esteem) Dengan Prestasi Belajar Pada Remaja SMKN 48 di Jakarta Timur. Econosains Jurnal Online Ekonomi dan Pendidikan, 10(2), 193-210.

Istiana. (2017). Perbedaan Harga Diri Remaja Ditinjau Dari Status Keluarga Pada SMA Al -Ulum. Jurnal Psikologi Konseling 10(1).

Knafl, K. A., Deatrick, J. A., Knafl, G. J., Gallo, A. M., Grey, M., \& Dixon, J. (2013). Patterns Of Family Management Of Childhood Chronic Conditions And Their Relationship To Child And Family Functioning. Journal Of Pediatric Nursing, 28(6), 523-535.

Lestari, S. 2012. Psikologi Keluarga: Penanaman Nilai Dan Penanganan Konflik Dalam Keluarga. Jakarta: Kencana Prenada Media Group.

Miranda, D. (2013). The Role Of Music In Adolescent Development: Much More Than The Same Old Song. International Journal of Adolescence and Youth, 18(1), 5-22.

Muarifah, A., Widyastuti, D. A., \& Fajarwati, I. (2019). The Effect of Social Support on Single Mothers' Subjective WellBeing and Its Implication for Counseling. Jurnal Kajian Bimbingan dan Konseling, 4(4), 143-149.

Myers, D. G. . (2015). Psikologi Sosial, Edisi ke-12. New York: Mc Grew-Hill Companies, Inc

Nikmarijal, N. (2014). Urgensi Peranan Keluarga bagi Perkembangan Self- 
esteem Remaja. Jurnal Konseling dan Pendidikan, 2(2).

Porche, M. V., Costello, D. M., \& RosenReynoso, M. (2016). Adverse Family Experiences, Child Mental Health, And Educational Outcomes For A National Sample Of Students. School Mental Health, 8(1), 44-60.

Rahman, A. A. (2013). Psikologi Sosial: Integrasi Pengetahuan Wahyu dan Pengetahuan Empirik. Jakarta: Raja Grafindo Persada.

Rangkuti \& Mardiawan. 2015. Hubungan antara Self Esteem dengan Perilaku Compulsive Bulying pada Remaja Anggota Hansamo. Prosiding Psikologi. ISSN: 2460-6448

Refnadi, R. (2018). Konsep Self-Esteem Serta Implikasinya Pada Remaja. Jurnal EDUCATIO Jurnal Pendidikan Indonesia, 4(1), 16-22.

Sperry, L. (2013). Integrated Behavioral Health: Implications For Individual And Family Counseling Practice. The Family Journal, 21(3), 347-350.

Srisayekti, W. Setiady, D.A., dan Sanitioso, R.B. (2015). Harga-diri (Self-esteem) Terancam dan Perilaku Menghindar. Jurnal Psikologi, 42(2), 141-156.

Wangge \& Hartini. (2013). Hubungan antara Penerimaan Diri dengan Harga Diri pada Remaja Pasca Perceraian Orangtua. Jurnal Psikologi Kepribadian dan Sosial, 2(1).

Wibowo, S. B. (2014). Benarkah Self-Esteem Mempengaruhi Prestasi Akademik? Jurnal Humanitas, 13(1), 72-83 